\title{
Pengaruh Jenis Bahan Tanam dan Konsentrasi Rootone-F terhadap Keberhasilan Pertumbuhan Mucuna bracteata D.C
}

The type of planting material and the concentration of Rootone-F treatment to success of Mucuna bracteata D.C growth.

\author{
Hariyadi* dan Asqian Satria Anindito
}

Departemen Agronomi dan Hortikultura, Fakultas Pertanian, Institut Pertanian Bogor (Bogor Agricultural University), Jl. Meranti, Kampus IPB Darmaga, Bogor 16680, Indonesia

Telp. \& Faks.62-251-869353 e-mail agronipb@indo.net.id

*Penulis untuk korespondensi: hariyadibogor@yahoo.com

Disetujui 17 Mei 2017/Published online 22 Mei 2017

\begin{abstract}
This research is to observe and compare the concentration of Rootone-F and the type of planting material to success of Mucuna bracteata growth. This research is conducted in June until September in 2015 in Leuwikopo Field Laboratory, Horticulture and Agronomy Department, IPB. The research used randomized complete block design with three repetitions of two factors. The first factor is the concentration of Rootone-f of five extents: 0,200, 400, 600 and 800 ppm. The second factor is the type of planting material consisting of three types: seed, young branch, medium branch. The results showed the type of planting material significant effect on observation parameter: the length of tendrils, number of leaves, number of branches, the dry weight of crowns, and the percentage of live plants. The result of the use of Rootone-F showed a significant effect on observation parameter: number of branches, number of leaves and the dry weight of the plant. There was a real interaction between the type of planting material and Rootone-F concentration on the parameter of branch amount and the dry weight of the crown.
\end{abstract}

Keyword: Legume Cover Crop, plant growth material, plant propagation, tendrils

\section{ABSTRAK}

Penelitian bertujuan mengamati dan membandingkan konsentrasi Rootone-F dan jenis bahan tanam terhadap keberhasilan pertumbuhan Mucuna bracteata. Penelitian dilakukan pada bulan Juni sampai September 2015 di Laboratorium Lapangan Leuwikopo, Departemen Agronomi dan Hortikultura, IPB. Penelitian menggunakan Rancangan Kelompok Lengkap Teracak dua faktor dengan tiga ulangan. Faktor pertama adalah konsentrasi Rootone-f terdiri atas lima taraf, yaitu 0, 200, 400, 600 dan 800 ppm. Faktor kedua adalah jenis bahan tanam yang terdiri atas tiga jenis, yaitu benih, ujung sulur, tengah sulur. Hasil penelitian menunjukan jenis bahan tanam berpengaruh nyata pada peubah pengamatan panjang sulur, jumlah daun, jumlah cabang, bobot kering tajuk, dan pesentase tanaman hidup.Hasil penggunaan konsentrasi Rootone-F menunjukan pengaruh yang nyata pada peubah pengamatan jumlah cabang, jumlah daun dan bobot kering tanaman.Terdapat interaksi yang nyata antara jenis bahan tanam dan konsentrasi Rootone-F pada parameter pengamatan jumlah cabang dan bobot kering sulur.

Kata kunci : Legume Cover Crop, perbanyakan tanaman, sulur, zat pengatur tumbuh 


\section{PENDAHULUAN}

Indonesia memiliki potensi lahan kering yang sesuai untuk budidaya pertanian yang sangat besar yaitu sekitar 76.2 juta ha yang sebagian besar (70.7 juta ha) terletak di dataran rendah dan sisanya di dataran tinggi. Sebagian besar lahan kering merupakan lahan berlereng $(>3 \%)$ yaitu sekitar $77 \%$ dengan topografi datar, agak berombak, berombak, berbukit sampai bergunung dan sisanya adalah lahan datar $(<3 \%)$ (Juarsa et al., 2008). Secara umum, lahan kering ini digunakan untuk budidaya tanaman pertanian dan perkebunan. Salah satu perkebunan yang memanfaatkan lahan kering ini adalah perkebunan kelapa sawit. Perkebunan kelapa sawit membutuhkan area yang luas dan tidak harus datar, sehingga pemanfaatan lahan kering di Indonesia untuk perkebunan kelapa sawit menjadi lebih efektif.

Hasil penelitian Widodo dan Dasanto (2010) menemukan bahwa perkembangan luas areal perkebunan kelapa sawit berdampak nyata terhadap lingkungan, diantaranya adalah semakin berkurangnya ketersediaan air, tanaman kelapa sawit secara ekologis merupakan tanaman yang paling banyak membutuhkan air dalam proses pertumbuhannya, yaitu sekitar 4,10-4,65 $\mathrm{mm}$ per hari dibandingkan dengan tanaman perkebunan lainnya. Tanaman keras membutuhkan air sekitar 5,02-6,32 $\mathrm{mm}$ per hari dan tanaman semusim membutuhan air sekitar $1.83-4.13 \mathrm{~mm}$ per hari untuk pertumbuhan dan produktivitasnya. Hal ini membutuhkan upaya konservasi air untuk mengimbangi ketersediaan air pada perkebunan di lahan kering.

Tanaman Mucuna bracteata merupakan salah satu tanaman kacang-kacangan yang pertama kali ditemukan di areal hutan Negara bagian Tripura, India Utara, dan telah ditanam secara luas sebagai penutup tanah di Perkebunan Karet Kerala, India Selatan. Mucuna bracteata memiliki daun trifoliat berwarna hijau gelap dengan ukuran $15 \mathrm{~cm}$ x $10 \mathrm{~cm}$. Helaian daun akan menutup apabila suhu lingkungan terlalu tinggi (termonasti), sehingga sangat efisien dalam mengurangi penguapan permukaan. Ketebalan vegetasi Mucuna bracteata dapat mencapai 40$100 \mathrm{~cm}$ dari permukaan tanah. (Harahap et al., 2008) menyatakan bahwa pada kultur teknis yang standar, laju penutupan kacangan pada masa awal penanaman dapat mencapai $2-3 \mathrm{~m}^{2}$ per bulan. Penutupan areal secara sempurna dicapai saat memasuki tahun ke dua dengan ketebalan vegetasi berkisar 40-100 $\mathrm{cm}$ dan biomassa berkisar antara 9-12 ton bobot kering per ha. Hara nitrogen pada tumbuhan kacang-kacangan sebanyak $66 \%$ berasal dari gas $\mathrm{N}^{2}$ hasil simbiosis dengan bakteri rhizobium. Fiksasi nitrogen yang dilakukan oleh tanaman kacang-kacangan sering mengalami hambatan. Fiksasi nitrogen dipengaruhi oleh faktor lingkungan seperti $\mathrm{pH}$ tanah, kandungan nutrisi yang minimum, suhu yang terlampau ekstrim, kelebihan atau kekurangan kandungan air dalam tanah (Vissoh, 2005).

Berdasarkan pengaruhnya terhadap kesuburan tanah ternyata tanaman penutup tanah Mucuna bracteata memenuhi syarat sebagai tanaman penutup tanah. Tanaman ini penghasil bahan organik yang tinggi dan akan sangat bermanfaat jika ditanam di daerah yang sering mengalami kekeringan dan pada daerah dengan kandungan bahan organik rendah.

Perbanyakan tanaman menggunakan stek lebih mudah dan cepat dilakukan dibandingkan dengan cara perbanyakan vegetatif lainnya. Tanaman hasil perbanyakan stek tidak memiliki akar tunggang sehingga kurang kuat pengakarannya. Pemilihan bahan stek penting dilakukan karena berhubungan dengan kecepatan tumbuh akar. Bahan stek berupa batang dengan warna kulit bagian dalam yang terlihat kehijauan menandakan adanya kandungan auksin, nitrogen, dan karbohidrat yang tinggi sehingga akan cepat menimbulkan akar (Agung, 2007). Stek batang yang terlalu tua akan mempersulit proses tumbuh akar dan memerlukan perlakuan khusus seperti pemberian zat pengatur tumbuh yang dapat menginisiasi pengakaran. Tujuan dari penelitian ini untuk mengetahui pengaruh jenis bahan tanam dan dosis zat pengatur tumbuh Rootone-F terhadap keberhasilan pertumbuhan Mucuna bracteata

\section{METODE PENELITIAN}

Penelitian ini dilaksanakan mulai bulan Juli 2015 sampai September 2015. Percobaan dilaksanakan di TF Leuwikopo Kampus IPB Dramaga pada ketinggian 250 mdpl. Bahan yang digunakan adalah bahan stek batang Mucuna bracteata, benih Mucuna bracteata, pupuk NPK, pupuk kandang, Rootone-F, Rhizobium, dan fungisida. Peralatan yang digunakan antara lain neraca analitik, gunting pangkas, peralatan pengukuran panjang, oven dan alat penunjang lainnya.

Penelitian menggunakan Rancangan Kelompok Lengkap Teracak (RKLT) faktorial dengan dua faktor yaitu jenis bahan tanam dan konsentrasi Rootone - F. Faktor pertama yaitu dengan mengunakan benih/ kontrol (A0), ujung sulur( A1), dan tengah sulur (A2). Faktor kedua yaitu konsentrasi Rootone - F terdiri dari 0 ppm 
(B0), 200 ppm (B1), 400 ppm (B2), 600 ppm (B3), dan 800 ppm (B4). Terdapat 15 kombinasi perlakuan pada setiap ulangan dengan 3 kali pengulangan sehingga terdapat 45 satuan percobaan. Jika terdapat pengaruh nyata dari perlakuan yang diuji berdasarkan uji ragam pada taraf 5\%, maka dilakukan uji lanjut untuk melihat perbedaan antar perlakuan dengan uji Duncan Multiple Range Test (DMRT) pada taraf 5\% (Gomez dan Gomez, 1995).

Media tanam yang digunakan merupakan campuran dari pupuk organik dan tanah yang berasal dari daerah sekitar penanaman dengan perbandingan 1:2. Kemudian media tanam dimasukan ke dalam polibag ukuran 10x15 cm dan disusun di bedengan. Bedengan dibuat dengan ukuran $1 \mathrm{~m}$ x 2 m sebanyak tiga bedeng. Terdapat 150 tanaman pada setiap bedeng, sehingga terdapat 450 tanaman pada penelitian.

Benih Mucuna bracteata yang digunakan adalah benih yang berasal dari Pusat Penelitian Kelapa Sawit. Benih Mucuna bracteata terlebih dahulu dilakukan proses skarifikasi secara manual lalu disemai pada polibag. Bibit Mucuna bracteata ditempatkan pada tempat yang terlindung dari sinar matahari langsung dan terpaan air hujan. Penyiraman dilakukan satu kali dalam sehari yaitu pada saat pagi atau sore hari. Bibit Mucuna bracteata diberi pupuk daun dengan konsentrasi $2 \mathrm{~g} \mathrm{l}^{-1}$.

Bahan tanam Mucuna bracteata yang digunakan berupa stek batang yang berasal dari Kebun Percobaan leuwikopo IPB Darmaga Bogor. Stek batang Mucuna bracteata diusahakan diambil dengan ukuran dan umur yang seragam dengan keadaan segar dipagi hari. Daun pada buku bawah dipotong agar mengurangi tingkat penguapan. Tiap individu stek memiliki dua ruas lalu bahan stek direndam dengan berbagai konsentrasi Rootone - F sesuai perlakuan selama 15 menit. Selanjutnya stek Mucuna bracteata ditanam dengan membenamkan satu ruas di dalam tanah dengan posisi tegak dan diberi label sesuai dengan perlakuan dan disungkup dengan plastik.

Pengamatan tanaman yang dilakukan meliputi: panjang sulur, yaitu dengan cara menghitung panjang sulur dari bagian pangkal tunas sampai dengan bagian ujung sulur pada titik tumbuh tangkai daun. Pengamatan dilakukan setiap minggu mulai dari 2 MST sampai dengan 10 MST. Pengamatan jumlah daun tumbuh, yaitu jumlah daun trifoliat yang telah membuka sempurna. Pengamatan dilakukan setiap minggu mulai umur 2 MST sampai dengan 10 MST.
Pengamatan bobot kering tanaman, yaitu bobot tanaman kering yang berasal dari tiap parameter percobaan yang ditimbang setelah sebelumnya dilakukan pembersihan dan pengovenan pada suhu $70^{\circ} \mathrm{C}$ selama 72 jam. Persentase tanaman hidup, yaitu jumlah tanaman yang hidup diakhir penelitian dibagi dengan jumlah tanaman yang ditanam dikali dengan seratus persen. Pengamatan dilakukan diakhir pengamatan yaitu 10 MST. Pengamatan terakhir yaitu jumlah cabang yang terdapat pada satu tanaman, yang dilakukan tiap minggu mulai dari 2 MST sampai dengan 10 MST

\section{HASIL DAN PEMBAHASAN}

\section{Kondisi Umum}

Berdasarkan data curah hujan BMKG (2015) pada bulan Juli 2015 hingga bulan Oktober 2015, didapatkan jumlah hujan rata-rata sebesar $76 \mathrm{~mm} /$ bulan (rendah) dengan curah hujan terendah pada bulan juli yaitu $1.6 \mathrm{~mm} / \mathrm{bulan}$ (rendah) dan curah hujan tertinggi pada bulan agustus $112.4 \mathrm{~mm} / \mathrm{bulan}$ (menengah). Jumlah curah hujan yang rendah pada awal pertanaman mempengaruhi pertumbuhan tinggi tanaman, jumlah cabang, jumlah daun, persentase tanaman hidup,dan bobot tanaman. Tindakan yang dilakukan untuk mengatasi masalah tersebut adalah dengan melakukan penyiraman pada pagi dan sore hari sehingga diharapkan kebutuhan air tanaman dapat dipenuhi. Setelah diamati ternyata terdapat bibit yang terserang cendawan Rhizoctonia solani, akibat cendawan ini bagian pangkal tanaman membusuk dan berwarna coklat sampai hitam. Cendawan membentuk miselium berwarna putih, karena itu intensitas penyiram dikurangi menjadi satu kali sehari yaitu pada pagi hari.

Pertumbuhan tunas dimulai pada 1 MST akan tetapi pengamatan baru dimulai pada umur 2 MST. Hal ini diakibatkan oleh pertumbuhan tanaman yang masih lambat pada awal masa pertanaman.

\section{Panjang Sulur}

Sulur merupakan bagian batang tanaman tempat tumbuhnya cabang serta daun tanaman, sulur juga berfungsi sebagai alat tumbuhan untuk merambat dan melekatkan diri pada tanaman di sekitarnya dan memperbanyak jumlah daun. Dengan adanya peningkatan sulur tanaman maka jumlah daun akan bertambah dan meningkatkan proses fotosintesis 
Tabel 1 Rata-rata panjang sulur terhadap perlakuan jenis bahan tanam dan konsentrasi Rootone-F

\begin{tabular}{|c|c|c|c|c|c|c|c|c|c|}
\hline \multirow{2}{*}{ Perlakuan } & \multicolumn{9}{|c|}{ Umur (MST) } \\
\hline & 2 & 3 & 4 & 5 & 6 & 7 & 8 & 9 & 10 \\
\hline \multirow[t]{2}{*}{ Bahan tanam } & \multicolumn{9}{|c|}{ 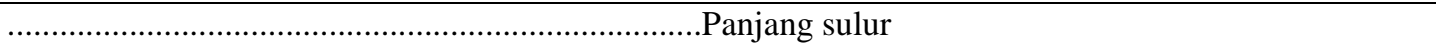 } \\
\hline & \multicolumn{9}{|c|}{$(\mathrm{cm})$} \\
\hline Benih & $5,63 \mathrm{c}$ & $16,91 \mathrm{c}$ & $29,78 \mathrm{c}$ & $42,54 \mathrm{c}$ & $55,88 \mathrm{c}$ & $69,37 \mathrm{c}$ & $82,12 \mathrm{c}$ & $96,76 \mathrm{c}$ & $112,14 \mathrm{c}$ \\
\hline Ujung sulur & $12,53 \mathrm{~b}$ & $27,08 \mathrm{~b}$ & $41,98 \mathrm{~b}$ & $57,50 \mathrm{~b}$ & $73,18 b$ & $89,36 \mathrm{~b}$ & $106,84 \mathrm{~b}$ & $123,46 \mathrm{~b}$ & $140,62 \mathrm{~b}$ \\
\hline Tengah Sulur & $17,38 \mathrm{a}$ & $36,40 \mathrm{a}$ & $55,73 \mathrm{a}$ & $76,51 \mathrm{a}$ & $98,03 \mathrm{a}$ & $119,33 \mathrm{a}$ & $141,79 \mathrm{a}$ & $164,50 \mathrm{a}$ & $188,08 \mathrm{a}$ \\
\hline \multicolumn{10}{|l|}{$\begin{array}{l}\text { Rooton }-\mathrm{F} \\
(\mathrm{ppm})\end{array}$} \\
\hline 0 & 11,5 & 25,83 & 40,55 & 56,68 & 73,78 & 89,37 & 106,56 & 123,86 & 142,48 \\
\hline 200 & 11,6 & 26,66 & 42,23 & 58,45 & 75,62 & 92,62 & 111,27 & 128,11 & 147,25 \\
\hline 400 & 11,28 & 26,13 & 42,1 & 58,67 & 74,62 & 91,76 & 107,90 & 126,97 & 144,95 \\
\hline 600 & 12,43 & 27,97 & 44,07 & 60,91 & 78,03 & 95,81 & 113,81 & 132,40 & 151,61 \\
\hline 800 & 12,38 & 27,38 & 43,54 & 59,54 & 76,46 & 93,86 & 111,72 & 129,85 & 148,43 \\
\hline Interaksi & 0,994 & 0,999 & 0,992 & 0,991 & 0,993 & 0,980 & 0,957 & 0,999 & 0,997 \\
\hline Notasi & tn & $\operatorname{tn}$ & $\operatorname{tn}$ & $\operatorname{tn}$ & $\operatorname{tn}$ & tn & $\operatorname{tn}$ & $\operatorname{tn}$ & $\operatorname{tn}$ \\
\hline
\end{tabular}
uji DMRT pada taraf $\alpha=5 \%$, tn= tidak berbeda nyata

Hasil sidik ragam menunjukkan bahwa pengaruh perlakuan asal bahan tanam (A) berbeda nyata, sedangkan pengaruh perlakuan konsentrasi Rootone-F (B) tidak berbeda nyata terhadap panjang tunas pada setiap waktu pengamatan. Tidak terdapat interaksi AxB pada setiap umur pengamatan. Hasil pengamatan panjang tunas dapat dilihat pada Tabel 1 .

Berdasarkan uji DMRT 5\% perlakuan jenis bahan tanam menunjukkan perlakuan berbeda nyata dengan pada setiap umur pengamatan. Perlakuan stek tengah sulur mendorong pembentukan tunas lebih panjang dari perlakuan benih. Hal ini diduga karena kandungan karbohidrat maupun hormon endogen yang tersedia di dalam bahan tanam sudah optimum untuk memicu proses differensiasi sel
(Hartman et al.,1990). Respon fisiologis tanaman terhadap pemberian auksin secara eksogen adalah merangsang pembelahan, perpanjangan sel dan pertumbuhan tanaman tetapi apabila pemberian zat pengatur tumbuh tidak berimbang maka akan mengganggu proses pembelahhan sel (Thimann, 1977)

\section{Jumlah Cabang}

Hasil sidik ragam menunjukkan bahwa pengaruh perlakuan asal bahan stek (A) dan perlakuan konsentrasi Rootone-F (B) berbeda nyata terhadap panjang tunas. Terdapat interaksi AxB pada umur 9 dan10 MST. Hasil pengamatan jumlah daun dapat dilihat pada Tabel 2

Tabel 2 Rata-rata jumlah cabang terhadap perlakuan bahan tanam dan konsentrasi Rootone-F

\begin{tabular}{|c|c|c|c|c|c|c|c|c|c|}
\hline \multirow{2}{*}{ Perlakuan } & \multicolumn{9}{|c|}{ Umur (MST) } \\
\hline & 2 & 3 & 4 & 5 & 6 & 7 & 8 & 9 & 10 \\
\hline Bahan tanam & \multicolumn{9}{|c|}{ 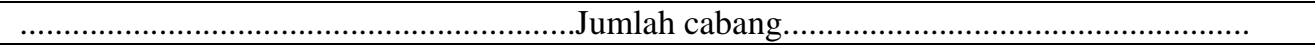 } \\
\hline Benih & 1 & 1 & 1 & $1 \mathrm{~b}$ & $1 \mathrm{~b}$ & $2 \mathrm{~b}$ & $2 \mathrm{~b}$ & $2 \mathrm{c}$ & $2 \mathrm{c}$ \\
\hline Ujung Sulur & 1 & 1 & 1 & $2 \mathrm{a}$ & $2 \mathrm{a}$ & $2 b$ & $3 a$ & $3 b$ & $3 b$ \\
\hline Tengah Sulur & 1 & 1 & 1 & $2 \mathrm{a}$ & $2 \mathrm{a}$ & $3 \mathrm{a}$ & $3 \mathrm{a}$ & $4 \mathrm{a}$ & $4 \mathrm{a}$ \\
\hline
\end{tabular}

Rooton $-\mathrm{F}$

(ppm)

\begin{tabular}{llllllllll}
\hline 0 & 1 & 1 & 1 & 1 & 2 & 2 & $2 \mathrm{~b}$ & $2 \mathrm{~b}$ & 3 \\
200 & 1 & 1 & 1 & 1 & 2 & 2 & $2 \mathrm{~b}$ & $3 \mathrm{a}$ & 3 \\
400 & 1 & 1 & 1 & 1 & 2 & 2 & $3 \mathrm{a}$ & $3 \mathrm{a}$ & 3 \\
600 & 1 & 1 & 1 & 2 & 2 & 2 & $3 \mathrm{a}$ & $3 \mathrm{a}$ & 3 \\
800 & 1 & 1 & 1 & 2 & 2 & 2 & $3 \mathrm{a}$ & $3 \mathrm{a}$ & 3 \\
\hline Interaksi & - & 0,857 & 0,899 & 0,824 & 0,478 & 0,540 & 0,351 & 0,006 & 0,008 \\
Notasi & th & th & th & tn & th & th & th & $*$ & $*$ \\
\hline
\end{tabular}

Keterangan : angka-angka yang diikuti huruh berbeda pada kolom yang sama menunjukkan perbedaan yang nyata menurut uji DMRT pada taraf $\alpha=5 \%, \mathrm{tn}=$ tidak berbeda nyata, $*=$ berbeda nyata

Berdasarkan tabel 2 faktor bahan tanam baru menunjukkan hasil yang berbeda nyata pada umur 5 MST sampai dengan 10 MST. Bahan tanam yang berasal dari stek tengah sulur menunjukkan jumlah cabang yang paling banyak, sedangkan bahan tanam yang berasal dari benih 
menunjukkan pertumbuhan jumlah cabang yang paling sedikit. Faktor konsentarsi Rootone-F baru menunjukkan hasil yang berbeda nyata pada 8 dan
9 MST hal ini menunjukkan bahwa tanaman Mucuna bracteata baru merespon perlakuan Rootone-F pada umur 8 MST.

Tabel 3 Interaksi konsentrasi Rootone-F dan jenis bahan tanam pada jumlah cabang umur 9 MST

\begin{tabular}{|c|c|c|c|}
\hline \multirow{2}{*}{$\begin{array}{l}\text { Konsentrasi } \\
\text { Rootone-F }\end{array}$} & \multicolumn{3}{|c|}{ Bahan Tanam } \\
\hline & Benih (A0) & Ujung Sulur (A1) & Tengah Sulur (A2) \\
\hline & \multicolumn{3}{|c|}{ 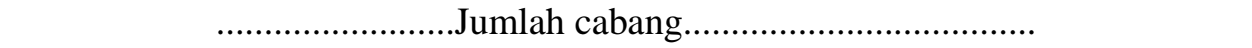 } \\
\hline 0 ppm & $2 \mathrm{bc}$ & $2 \mathrm{bc}$ & $3 a b$ \\
\hline 200 ppm & $2 \mathrm{bc}$ & $3 a b$ & $3 \mathrm{ab}$ \\
\hline 400 ppm & $2 \mathrm{bc}$ & $3 a b$ & $3 a b$ \\
\hline $600 \mathrm{ppm}$ & $2 \mathrm{bc}$ & $3 a b$ & $4 \mathrm{a}$ \\
\hline 800 ppm & $2 \mathrm{bc}$ & $3 a b$ & $4 \mathrm{a}$ \\
\hline \multicolumn{4}{|c|}{ Keterangan : angka-angka yang diikuti oleh huruf yang berbeda menunjukkan berbeda nyata menurut Uji DMRT pada taraf $\alpha=5 \%$} \\
\hline \multicolumn{2}{|c|}{$\begin{array}{l}\text { Kombinasi perlakuan pada umur } 9 \text { MST } \\
\text { (Tabel 3) yang menunjukkan hasil tertinggi } \\
\text { terhadap jumlah cabang terdapat pada kombinasi } \\
\text { perlakuan jenis bahan tanam stek tengah sulur } \\
\text { dengan konsentrasi Rootone-F } 600 \text { dan } 800 \mathrm{ppm}\end{array}$} & \multicolumn{2}{|c|}{$\begin{array}{l}\text { tertinggi diantara bahan tanam lain sebanyak } 4 \\
\text { cabang. Sedangkan jumlah cabang tanaman } \\
\text { terendah terdapat pada kombinasi perlakuan jenis } \\
\text { bahan tanam benih dengan semua konsentrasi } \\
\text { Rootone-F sebesar } 2 \text { cabang. }\end{array}$} \\
\hline \multicolumn{4}{|c|}{ Tabel 4 Interaksi konsentrasi Rootone-F dan jenis bahan tanam pada jumlah cabang umur 10 MST } \\
\hline \multirow{2}{*}{$\begin{array}{l}\text { Konsentrasi } \\
\text { Rootone-F }\end{array}$} & \multicolumn{3}{|c|}{ Bahan Tanam } \\
\hline & Benih (A0) & Ujung Sulur (A1) & Tengah Sulur (A2) \\
\hline \multicolumn{4}{|c|}{.......Jumlah cabang.... } \\
\hline 0 ppm & $2 \mathrm{~cd}$ & $2 \mathrm{~cd}$ & $4 a b$ \\
\hline $200 \mathrm{ppm}$ & $2 \mathrm{~cd}$ & $3 \mathrm{bc}$ & $4 a b$ \\
\hline $400 \mathrm{ppm}$ & $2 \mathrm{~cd}$ & $3 \mathrm{bc}$ & $4 \mathrm{ab}$ \\
\hline $600 \mathrm{ppm}$ & $2 \mathrm{~cd}$ & $3 \mathrm{bc}$ & $5 \mathrm{a}$ \\
\hline $800 \mathrm{ppm}$ & $2 \mathrm{~cd}$ & $4 \mathrm{ab}$ & $4 a b$ \\
\hline
\end{tabular}

Keterangan : angka-angka yang diikuti oleh huruf yang berbeda menunjukkan berbeda nyata

Kombinasi perlakuan pada umur 10 MST (Tabel 4) yang menunjukkan hasil tertinggi terhadap jumlah cabang terdapat pada kombinasi perlakuan jenis bahan tanam stek tengah sulur dengan konsentrasi Rootone-F 600 ppm tertinggi diantara bahan tanam lain sebanyak 5 cabang. Sedangkan jumlah cabang tanaman terendah terdapat pada kombinasi perlakuan jenis bahan tanam benih dengan semua konsentrasi RootoneF sebesar 2 cabang.

\section{Jumlah Daun}

Hasil sidik ragam menunjukkan bahwa pengaruh perlakuan asal bahan tanam (A) berbeda nyata pada 2 sampai 10 MST, sedangkan pengaruh perlakuan konsentrasi Rootone-F (B) berbeda nyata terhadap panjang tunas pada 9 dan 10 MST. Tidak terdapat interaksi AxB pada setiap umur pengamatan. Hasil pengamatan jumlah daun dapat dilihat pada Tabel 4.

Tabel 5 Rata-rata jumlah daun terhadap perlakuan jenis bahan tanam dan konsentrasi Rootone-F

\begin{tabular}{|c|c|c|c|c|c|c|c|c|c|}
\hline \multirow{2}{*}{ Perlakuan } & \multicolumn{9}{|c|}{ Umur (MST) } \\
\hline & 2 & 3 & 4 & 5 & 6 & 7 & 8 & 9 & 10 \\
\hline Bahan tanam & & $\ldots$ & ........ & ......... & umlah d & $(\mathrm{cm}) .$. & ................. & ............. & \\
\hline Benih & $1 \mathrm{~b}$ & $2 \mathrm{c}$ & $3 \mathrm{c}$ & $4 \mathrm{c}$ & $5 \mathrm{c}$ & $6 c$ & $7 \mathrm{c}$ & $8 \mathrm{c}$ & $9 \mathrm{c}$ \\
\hline Ujung Sulur & $2 a$ & $3 \mathrm{~b}$ & $4 \mathrm{~b}$ & $5 \mathrm{~b}$ & $7 \mathrm{~b}$ & $8 \mathrm{~b}$ & $10 \mathrm{~b}$ & $12 \mathrm{~b}$ & $13 \mathrm{~b}$ \\
\hline Tengah Sulur & $2 \mathrm{a}$ & $4 \mathrm{a}$ & $5 \mathrm{a}$ & $7 \mathrm{a}$ & $9 \mathrm{a}$ & $11 \mathrm{a}$ & $13 \mathrm{a}$ & $15 \mathrm{a}$ & $17 \mathrm{a}$ \\
\hline \multicolumn{10}{|l|}{$\begin{array}{l}\text { Rooton }-\mathrm{F} \\
(\mathrm{ppm})\end{array}$} \\
\hline 0 & 1 & 3 & 4 & 5 & 7 & 8 & 10 & $11 \mathrm{~b}$ & $13 \mathrm{~b}$ \\
\hline 200 & 1 & 3 & 4 & 5 & 7 & 9 & 10 & $11 \mathrm{~b}$ & $13 \mathrm{~b}$ \\
\hline 400 & 1 & 3 & 3 & 5 & 7 & 8 & 10 & $11 \mathrm{~b}$ & $13 \mathrm{~b}$ \\
\hline 600 & 1 & 3 & 4 & 6 & 8 & 9 & 11 & $12 \mathrm{a}$ & $14 \mathrm{a}$ \\
\hline 800 & 1 & 3 & 4 & 6 & 7 & 9 & 10 & $11 \mathrm{~b}$ & $13 \mathrm{~b}$ \\
\hline Interaksi & 0,925 & 0,878 & 0,955 & 0,929 & 0,924 & 0,644 & 0,453 & 0,154 & 0,119 \\
\hline Notasi & tn & $\operatorname{tn}$ & $\operatorname{tn}$ & tn & $\operatorname{tn}$ & tn & tn & tn & tn \\
\hline
\end{tabular}

Keterangan : angka-angka yang diikuti huruf berbeda pada kolom yang sama menunjukkan perbedaan yang nyata menurut uji DMRT pada taraf $\alpha=5 \%$, tn $=$ tidak berbeda nyata 
Perlakuan konsentrasi Rootone $\mathrm{F}$ berpengaruh nyata pada umur 9 dan 10 MST. Hal ini diduga pada umur 9 dan 10 MST, sel-sel tanaman terpacu oleh pengaruh Rootone $F$. Sesuai dengan pendapat Rismunandar (1988), bahwa ZPT dapat mempercepat tumbuhnya akar, batang, dan daun tanaman. Sementara itu, perlakuan asal bahan stek (A) berbeda nyata kemungkinan disebabkan ukuran diameter sulur dari asal bahan tersebut berbeda ukurannya, sehingga jumlah daun yang dihasilkan berbeda pula. Napitupulu (2006) bahwa kondisi bahan stek kecil dengan diameter batang yang kecil menunjukkan bahwa jaringan-jaringan pada batang stek kecil belum sempurna terbentuk. Oleh karena itu pertumbuhan daun pada bahan stek yang berasal dari ujung sulur menjadi lebih lambat sehingga jumlah daun yang dihasilkan lebih sedikit.

Persentase hidup merupakan perbandingan antara jumlah tanaman yang hidup pada akhir penelitian dengan jumlah bahan tanam yang ditanam pada awal penelitian dikali dengan seratus persen. Hasil sidik ragam menunjukkan bahwa pengaruh perlakuan asal bahan stek (A) berbeda nyata, sedangkan pengaruh perlakuan konsentrasi Rootone-F (B) tidak berbeda nyata terhadap persentase tanaman hidup . Tidak terdapat interaksi $\mathrm{AxB}$ pada parameter persentase hidup. Hasil pengamatan persentase hidup dapat dilihat pada Tabel 6.

Tabel 6. Rata-rata persentase persentase daya hidup terhadap perlakuan jenis bahan tanam dan konsentrasi Rootone-F

\begin{tabular}{|c|c|}
\hline \multirow[t]{2}{*}{ Perlakuan } & Umur (MST) \\
\hline & 10 \\
\hline & Persentase hidup (\%) \\
\hline \multicolumn{2}{|l|}{$\begin{array}{l}\text { Bahan } \\
\text { tanam }\end{array}$} \\
\hline Benih & $58,0 \mathrm{~b}$ \\
\hline Ujung & $73,3 \mathrm{a}$ \\
\hline \multicolumn{2}{|l|}{ Sulur } \\
\hline Tengah & $74,0 \mathrm{a}$ \\
\hline \multicolumn{2}{|l|}{ Sulur } \\
\hline \multicolumn{2}{|l|}{$\begin{array}{l}\text { Rooton - F } \\
(\mathrm{ppm})\end{array}$} \\
\hline $0 \mathrm{ppm}$ & 71,1 \\
\hline $200 \mathrm{ppm}$ & 66,7 \\
\hline $400 \mathrm{ppm}$ & 68,9 \\
\hline $600 \mathrm{ppm}$ & 70,0 \\
\hline $800 \mathrm{ppm}$ & 65,5 \\
\hline Interaksi & 0,258 \\
\hline Notasi & tn \\
\hline Keterangan & $\begin{array}{l}\text { angka-angka yang diikuti huruf berbeda pada } \\
\text { kolom yang sama menunjukkan perbedaan } \\
\text { yang nyata menurut uji DMRT pada taraf } \\
\alpha=5 \% \text {, tn= tidak berbeda nyata }\end{array}$ \\
\hline
\end{tabular}

Persentase tanaman hidup asal benih memiliki persentase terendah karena adanya serangan cendawan. Serangan cendawan juga terdapat pada bahan tanam yang berasal dari stek, namun diduga bahan tanam yang beasal dari stek memiliki daya tahan yang lebih tinggi terhadap serangan cendawan.

\section{Bobot Kering Tanaman}

Pertumbuhan dapat diukur dari pertambahan biomassa yang dihasilkan tanaman. Pendekatan yang digunakan untuk pengukuran biomassa tanaman adalah dengan menimbang bobot kering tanaman (Sitompul dan Guritno, 1995). Bobot kering tanaman merupakan penimbunan hasil bersih asimilasi $\mathrm{CO}^{2}$ selama pertumbuhan. Semakin tinggi bobot kering maka reaksi metabolisme semakin baik karena tanaman memiliki daun yang kokoh sehingga proses fotosintesis berjalan lancar (Taufiq, 2000). Berat kering pucuk merupakan berat sulur setelah dioven dengan suhu $70^{\circ} \mathrm{C}$ selama $72 \mathrm{jam}$. Pengukuran bobot kering dilakukan pada akhir pengamatan (10 MST) dengan mengambil sampel dari setiap perlakuan. Data hasil pengamatan menunjukkan bahwa pada faktor bahan tanam bobot kering tanaman tertinggi pada bahan tanam tengah sulur dengan bobot 229,49 gr, sedangkan bobot kering tanaman terendah terdapat pada bahan tanam benih dengan bobot 137,98 gr. Hal ini diduga bahan tanam benih membutuhkan waktu lebih lama untuk dapat berkembang menjadi tanaman sempurna dibandingkan dengan bahan tanam stek tengah sulur. Pada faktor konsentrasi Rootone-F bobot kering tanaman tertinggi terdapat pada konsentrasi $600 \mathrm{ppm}$ dengan bobot 191,81 gr, sedangkan bobot kering tanaman terendah terdapat pada konsentrasi 0 ppm dengan bobot 176,05 gr. Hal ini disebakan konsentrasi 600 ppm menunjukkan pertumbuhan panjang sulur, jumlah daun dan jumlah cabang tertinggi.

Hasil sidik ragam menunjukkan bahwa pengaruh perlakuan asal bahan stek (A) berbeda nyata, pengaruh perlakuan konsentrasi Rootone-F (B) berbeda nyata terhadap parameter bobot kering tanaman pada pengamatan.Terdapat interaksi $\mathrm{AxB}$ pada pengamatan. Hasil pengamatan bobot kering tanaman dapat dilihat pada tabel 7 
Tabel 7. Pengaruh bahan tanam dan konsentrasi Rootone-F terhadap bobot kering tanaman

\begin{tabular}{lc}
\hline \multirow{2}{*}{ Perlakuan } & Umur (MST) \\
\cline { 2 - 2 } Bahan tanam & Bobot kering tanaman $(\mathrm{gr})$ \\
Benih & $137,98 \mathrm{c}$ \\
Ujung Sulur & $190,60 \mathrm{~b}$ \\
Tengah & $229,49 \mathrm{a}$ \\
Sulur & \\
\hline Rooton $-\mathrm{F}$ & \\
\hline 0 & $176,05 \mathrm{c}$ \\
200 & $187,04 \mathrm{~b}$ \\
400 & $188,26 \mathrm{~b}$ \\
600 & $191,81 \mathrm{a}$ \\
800 & $186,95 \mathrm{~b}$ \\
\hline Interaksi & 0,001 \\
Notasi & $*$ \\
\hline
\end{tabular}

Berdasarkan tabel 8 , kombinasi tertinggi menujukan bobot kering tanaman terdapat pada kombinasi perlakuan jenis bahan tanam stek tengah sulur dengan konsentrasi Rootone-F 600 ppm tertinggi diantara bahan tanam lain sebesar 239 gr ppm tetapi tidak berbeda nyata antara perlakuan stek tengah sulur dengan konsentrasi $600 \mathrm{ppm} 239 \mathrm{gr}$ dan stek tengah sulur dengan konsentrasi Rootone-F 400 ppm. Sedangkan bobot kering tanaman terendah terdapat pada kombinasi perlakuan jenis bahan tanam benih dengan konsentrasi Rootone-F 0 ppm.

Tabel 8 Interaksi konsentrasi Rootone-F dan jenis bahan tanam pada bobot kering tanaman umur 10 MST

\begin{tabular}{llll}
\hline \multirow{2}{*}{ Rotoone-F (ppm) } & Benih $(\mathrm{A} 0)$ & Stek ujung sulur $(\mathrm{A} 1)$ & Stek tengah sulur \\
\cline { 2 - 4 } $0 \mathrm{ppm}$ & $135,54 \mathrm{~h}$ & Bobot kering tanaman $(\mathrm{gr})$ & \\
\cline { 2 - 4 } $200 \mathrm{ppm}$ & $136,42 \mathrm{gh}$ & $172,13 \mathrm{f}$ & $221,50 \mathrm{c}$ \\
$400 \mathrm{ppm}$ & $141,36 \mathrm{~g}$ & $194,61 \mathrm{~d}$ & $230,10 \mathrm{~b}$ \\
$600 \mathrm{ppm}$ & $136,73 \mathrm{gh}$ & $188,43 \mathrm{e}$ & $235,00 \mathrm{ab}$ \\
$800 \mathrm{ppm}$ & $140,86 \mathrm{~g}$ & $199,70 \mathrm{~d}$ & $239,00 \mathrm{a}$ \\
\hline
\end{tabular}

Keterangan : angka-angka yang diikuti huruh berbeda menunjukkan perbedaan yang nyata menurut uji DMRT pada taraf $\alpha=5 \%$

\section{KESIMPULAN}

Perlakuan jenis bahan tanam berpengaruh nyata terhadap keberhasilan pertumbuhan Mucuna bractea pada parameter pengamatan panjang sulur, jumlah daun, jumlah cabang, bobot kering tanaman, dan persentase kehidupan. Jenis bahan tanam terbaik dalam menunjukkan keberhasilan pertumbuhan Mucuna bracteata adalah bahan tanam stek tengah sulur. Perlakuan konsentrasi Rootone-F berpengaruh nyata terhadap keberhasilan pertumbuhan Mucuna bracteata pada parameter pengamatan jumlah daun pada 9 MST dan 10 MST, jumlah cabang pada 7, 8, 9 dan 10 MST serta bobot kering tanaman pada 10 MST. Konsentrasi Rootone-F terbaik dalam menunjukkan keberhasilan pertumbuhan Muсuna bracteata adalah konsentrasi 600 ppm.

Kombinasi antara stek tengah sulur dengan konsentrasi Rootone-F 600 ppm menunjukkan kombinasi terbaik dalam keberhasilan pertumbuhan Mucuna bracteata pada parameter pengamatan jumlah cabang dan bobot kering tanaman pada 10 MST

\section{DAFTAR PUSTAKA}

Agung. 2007. Kunci Sukses Memperbanyak Tanaman. PT Agromedia Pustaka. Jakarta. 78 hal.

Gomez K.A. dan Gomez A.A.1995. Prosedur Statistika untuk Penelitian Pertanian (diterjemahkan dari : Stastitical Procedures for Agricultural Research, penerjemah : E. Sjamsudin dan J.S. Baharsjah). Jakarta (ID) : Universitas Indonesia

Harahap I. Y., Taufik C.H., Simangunsong G. dan Rahutomo R. 2008. Mucuna bracteata pengembangan dan pemanfaatannya di perkebunan kelapa sawit. Pusat Penelitian Kelapa Sawit., Medan.

Hartmann H.T., Kester D.E and Davies F.T. 1990. Plant propagation and practice. fifth $\mathrm{Ed}$. New Jersey (US) : Prentice Hall International

Juarsa I., Yustika R.D. dan Abdurachman A. 2008. Pengendalian erosi dan kahat bahan 
organik tanah pada lahan kering berlereng mendukung produksi pangan nasional. Di dalam: Anda M, Hendro B, Irawan, Surmaini E, Wahyunto, Husen E, editor. Prosiding Seminar Nasional dan Dialog Sumberdaya Lahan Pertanian, Buku II Teknologi Pengelolaan Sumberdaya Lahan. 2008 November 18-20; Bogor. Indonesia. Bogor (ID): Balai Besar Penelitian dan Pengembangan Sumberdaya Lahan Pertanian. hlm 249267.

Napitupulu R.M. 2006. Pengaruh bahan stek dan dosis zat pengatur tumbuh Rootone $\mathrm{F}$ terhadap keberhasilan stek Euphorbia mili. Skripsi. Program Studi Pemuliaan Tanaman dan Teknologi Benih. [skripsi]. Fakultas Pertanian. IPB, Bogor.

[PPKS] Pusat Penelitian Kelapa Sawit. 2011. Mucuna bracteata sebagai tanaman pengendali gulma: perbanyak-kannya dengan stek dan biji di Indonesia. [Internet] [diunduh [2011 Des 20] tersedia pada http://www.iopri.org

Rismunandar. 1988. Hormon Tumbuhan dan Ternak. Jakarta (ID): Penerbit Swadaya
Sitompul SM, Guritno B. 1995. Analisis Pertumbuhan Tanaman. Yogyakarta (ID): Gadjah Mada University Press.

Thimann K.V 1977. Hormone Action in Whole Life of Plants. Massachusetts (US): University of Massachusetts

Taufiq IS. 2000. Tingkat pemberian fosfor dalam media tanaman campuran ampas kecap Taufiq IS. 2000. Tingkat pemberian fosfor dalam media tanaman campuran ampas kecap bagi pertumbuhan tanaman jagung. [skripsi]. Bogor (ID): Institut Pertanian

Vissoh, P., Manyong V.M., Carsky J.R.., Oseibonsu P. and Galiba M. 2005. Experiences with Mucuna in West Africa. International Development Research Centre. $36 \mathrm{p}$

Widodo I.T. dan Dasanto B.D. 2010. Estimasi nilai lingkungan perkebunan kelapa sawit ditinjau dari neraca air tanaman kelapa sawit (studi kasus: perkebunan kelapa sawit di kecamatan dayun, kabupaten siak, propinsi riau. J.Agromet. 24 (1) : 2332. ISSN: 0126-3633. 